\title{
Localized Institutional Actors and Smallholder Irrigation Scheme Performance in Limpopo Province of South Africa
}

\author{
Liboster Mwadzingeni $^{1, *(\mathbb{D})}$, Raymond Mugandani ${ }^{2} \mathbb{D}$ and Paramu Mafongoya ${ }^{1}$ \\ 1 School of Agriculture, Earth and Environmental Sciences, University of KwaZulu-Natal, Carbis Road, \\ Scottsville, Pietermaritzburg 3201, South Africa; Mafongoya@ukzn.ac.za \\ 2 Faculty of Natural Resources Management and Agriculture, Midlands State University, \\ Gweru 9055, Zimbabwe; mugandanir@gmail.com \\ * Correspondence: libomwadzi@gmail.com; Tel.: +27-740-601-8532
}

Received: 9 August 2020; Accepted: 18 September 2020; Published: 21 September 2020

\begin{abstract}
Poor performance bedeviling SISs in South Africa is attributed to poor institutional integration, consequently impacting service delivery. Despite this, local institutional actors (LIAs)' role has not been documented as a potential entry point to address poor performance and hence increase SISs' sustainability. This study sought to assess the role of LIAs on the performance of the Tshiombo irrigation scheme (TIS). Structured questionnaires, key informant interviews (KIIs), and focus group discussions (FDGs) were used for data collection. Yield data for sweet potato, the main crop grown in the scheme, was measured as a proxy indicator for performance. Ordinary least square regression model was used to assess the relationship between LIAs and scheme performance after reducing the data using principal component analysis. The study revealed that institutional factors such as community credit support, academic extension support, academic institution market and input support, community maintenance support, and community input support positively and significantly (at 5\% level) improved the yield by a margin of $0.49,0.12,0.1,0.36$, and 0.10 . Assessing institutional actors' interaction within each scheme will help develop linkages that will enable sustainability of irrigation schemes. Out scaling of research on LIAs on irrigation scheme performance enhances scheme performance.
\end{abstract}

Keywords: principal component analysis; sustainability; Tshiombo irrigation scheme; smallholder farmers; scheme management

\section{Introduction}

Investment in agriculture is the primary practical pathway to ending poverty, reducing hunger and inequality, particularly in countries where the agricultural sector is the primary source of income and livelihoods. Smallholder farmers, especially in Sub-Saharan Africa (SSA), make a substantial contribution to global food security [1]. However, many of these smallholder farmers, who depend on rain-fed agriculture, are highly vulnerable to climate change, particularly the increase in frequency and severity of the drought [2]. Several local and international institutional actors advocate for smallholder farming support, claiming that this will reduce imbalance and poverty in African and Asian countries [3]. Cereal crop yields in many SSA parts have stagnated, thereby increasing the prevalence of food and nutritional insecurity and poverty [4]. Improving agricultural productivity and food security in these farming systems, especially those located in marginal areas, is highly compelling.

Much of the debate on improving agricultural productivity and food security in marginal areas of South Africa has targeted SISs. These SIS are an alternative for transforming agrarian farming systems in South Africa, which is collapsing in the wake of low and unreliable rainfall patterns [5], coupled 
with poor water management. The problems of water management in SIS of South Africa are well documented [6-8]. The above state of affairs points to the need for improved water management as a weapon to improve yields and performance of SIS in the country. There is vast scholarly information documenting the importance of policy and institutions in water management [9-11] However, there is cursory literature documenting LIAs' role in the performance of irrigation schemes in South Africa [11], most of which are either non-functional or operating below average [12-14]

Agriculture contributes approximately 3\% of South Africa's GDP and 7\% of its formal employment, thereby providing livelihoods; food and income security [15]. In addition, agriculture exports in South Africa have been gradually rising by $13.6 \%$ per annum from 2008 to 2018 and represents $14.6 \%$ of South Africa's trade value [16]. Nonetheless, increased rainfall variability is an imminent threat to South Africa's agricultural productivity. Building on the idea that SIS could play a key role in transforming the agrarian farming systems of South Africa, hence, investment in the SIS is therefore a critical venture for the nation.

Approximately $10 \%$ of the cultivated land is under irrigation in South Africa, of which $3.3 \%$ is held under SIS [17]. These SIS play an essential role in South Africa's rural areas, where between 200,000 and 250,000 smallholder farmers own an average of 1.5 ha each [18,19]. Schemes are a source of employment, leverage rural poor livelihoods, boost pro-poor sustainable agriculture, and contribute to economic growth [20]. The SIS farmers in South Africa grow a wide range of field crops (maize, wheat sugarcane, sweet potato, and Irish potato) and vegetable crops (tomato, cabbages, carrot, onion, and spinach) and trees $[19,20]$. Farrow and sprinkler irrigation systems are commonly used to deliver water to plots from dams, weirs, and rivers [5]. However, the success of the schemes has been a subject of debate in the light of the dilapidated irrigation infrastructure, leading to underutilization of land and water resources [20]. These SIS are operated and managed by locals following irrigation management transfer (IMT) in the early 1990s [19]. Numerous institutions play different roles in the SIS.

Institutions are human-created formal and informal mechanisms that shape social expectations, interactions, and behavior [21,22]. Formal institutions are constitutions, contracts, and forms of governments, while informal institutions are traditions, customs, moral values, religious believes, and norms [22]. The formal institutional actors are officially sanctioned by formal institutional arrangements, while informal institutional actors are enforced outside officially sanctioned channels [23]. However, LIAs are either organizations, players, agents, enterprises, or social structures in which people cooperate and influence the behavior of individuals $[24,25]$ by setting rules, oversees/observe operations, provide services, and produce policies within their confines $[23,24,26]$. The interaction of LIAs influences resource sharing, communication, and interaction between multiple actors: resource users, managers, and stakeholders $[27,28]$. However, institutional actors' classification depends on the context on which they are operational [29]. Although it is possible to categorize LIAs in numerous ways in the context of institutional literature, for this study, three types of institutional actors considered were civic, private, and public that operate in TIS. However, the gaps in current knowledge about LIAs' roles in SIS impedes the potential magnitude of changes in institutions and social relations [23]. In the context of this study, the LIAs in SISs in Limpopo province are cooperatives, government agencies, traditional leaders, irrigation committees, private organizations, local communities, and academic institutions. Their interaction, inter-organizational structure, information exchange, patterns, similarity, and competitions affect their performance. They help bring new technology, business models, and novel mindset to cope with the changing environment and technology.

In light of the above state of affairs, putting a significant thrust on institutional diagnosis on smallholder irrigation farming can potentially transform rural farmers' lives. Studies have shown that LIAs could provide the best avenue for improving SISs' performance [30,31]. Previous studies show that critical linkages between formal and informal institutional actors are often ignored [32]. Poor institutional integration in SISs has a significant impact on poor performance [17]. Poor institutional challenges result in problems such as the lack of farmer participation in the maintenance of irrigation infrastructure, which subsequently threatens the collapse of irrigation schemes [30,31]. Institutional 
actors formulate the rules that govern human interaction, thereby reducing uncertainty and providing insight that helps to link diverse stakeholders [14]. Support services in most SIS are weak, which deprive farmers of critical networks that help them develop the necessary capacity to manage the scheme and their plots [12]. We posit that the decline in institutional capacity has reduced the performance of SIS in South Africa.

Evidence from Elinor Ostrom's research on the commons, institutions, and collective action which lead to the social ecological systems framework (SESF) show that institutional actors work together to solve social problems in a system with common pool resource and public good [33,34]. However, farmers' access to institutional actors, governance, and formal and informal rules [34] determines SIS's performance. Fanadzo and Ncube [35] noted that the extent to which an irrigation scheme performs is determined by institutional actors' effectiveness, creating, regulating, and monitoring informal and formal rules. Apart from formulating and regulating policies, institutional actors provide support services to the farmers like information, credit, raw materials [35], and moral support [24] in SIS, giving them the potential to be food secure and improve their livelihoods. In the SESF, the "Action Situation" is the mix of players-individuals and institutional actors-that decide on resource management, monitoring, have a purpose/strategic direction, and are related to different costs and benefits attached to action and output $[12,34]$. It was noted that the actor component's actions in the action situation of irrigation schemes in Limpopo province need to be addressed [24]. We acknowledge Keetelaar [36] for identifying actors in SIS and their roles and how they were related to scheme performance [36]. Indeed, it is possible to improve the performance of schemes if active institutional actors are in place; hence, there is a need to analyze their role on scheme performance.

In SIS, institutional actors range from international institutions like IMF, FAO, national institutions, and local institutions, which are instrumental in spearheading their performance goal. This article enhances the understanding of how LIAs in SIS facilitates improving the performance of SIS.

Previous studies of such nature have focused on the impact of schemes committees only [11]. Still, this study assessed the impact of LIAs-academic institutions, government agencies, irrigation committee, non-governmental organizations (NGOs), private organizations, traditional chiefs, and water users associations (WUAs) - that participate in SIS. Therefore, this study's focus was to identify LIAs' roles on SIS's performance of SIS in the Tshiombo irrigation scheme in Limpopo province of South Africa.

\section{Materials and Methods}

\subsection{Description of the Study Area}

This study was carried out in the Tshiombo irrigation scheme (TIS) in Vhembe district of Limpopo province, South Africa (Figure 1). Limpopo province has the majority (about 53\%) of the country's schemes given that 170 of the 302 SIS in South Africa are in the province [17]. Moreover, of the 170 SIS in the province, about $28 \%$ are either unutilized, lowly utilized, and moderately utilized [20]. In addition, TIS has the largest command area in the Limpopo province of 847 ha [17]. Therefore, this case study will be a significant reference to the region, which is experiencing limited performance of irrigation schemes. The agroecology of the area is characterized by arid and semi-arid climatic environments, which are a significant challenge for rain-fed crop production. The total average annual rainfall is $\pm 560 \mathrm{~mm}$. However, the rainfall is highly variable and characterized by an increase in frequency and severity of mid-season dry spells, while droughts have become common in the area [37]. The average temperature in summer is around $27^{\circ} \mathrm{C}$, though temperatures can rise to 45 and $50{ }^{\circ} \mathrm{C}$ [38]. The main crops grown in the scheme include sweet potato, maize, beans, cabbages, groundnuts, and spinach. 


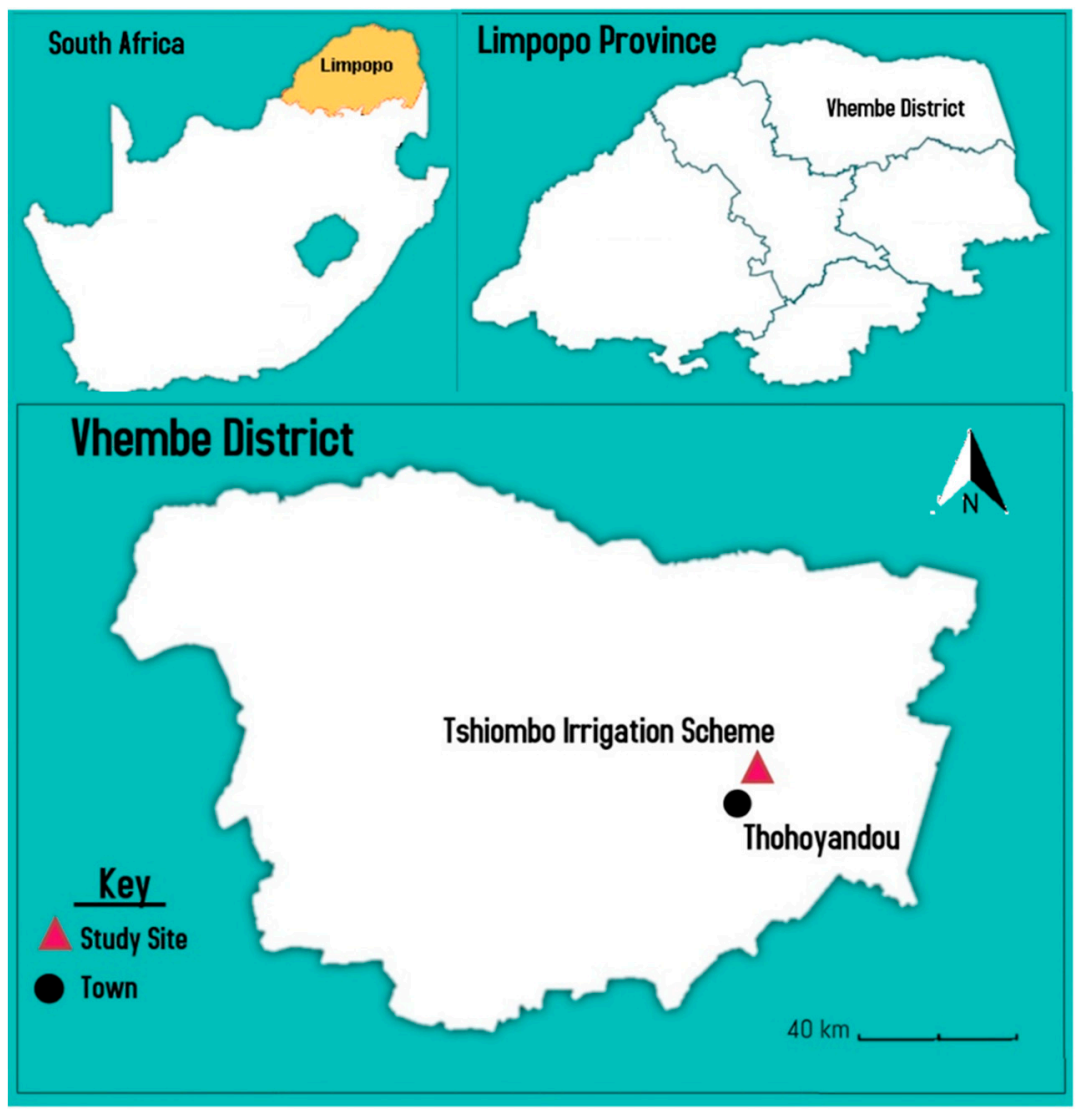

Figure 1. Study site, Limpopo province (Source: Author).

\subsection{Sampling Technique and Sample Size}

The total number of farmers in TIS is 840 . Therefore, assuming a $5 \%$ error margin, a confidence level of $95 \%$, and a response rate of $50 \%$ for our population, one hundred and forty-eight scheme farmers were randomly selected. The irrigation scheme was stratified into head, middle, and tail sections. Proportionate stratified random sampling was used to ensure equal representation of all participants. Forty-nine participants were randomly selected from each stratum, and trained Vhenda fluent interviewers administered questionnaires.

\subsection{Data Source and Method of Data Collection}

Data were collected on demographic variables, agronomic practices, water management practices employed by farmers, and LIAs and their roles in the scheme. Face-to-face interviews were conducted using a structured questionnaire as the primary data collection tool-the survey composed of both open and closed-end questions.

The questionnaire was pilot tested to assess its potential challenges, identify areas where research protocols may have been breached and test the measuring instrument's effectiveness. To answer the question on the role of LIAs, farmers were asked to select all the services which they access from each LIA. Responses that include credit/loan, input/output market, extension services, market/price information, input supply, and irrigation scheme maintenance were provided on the key. However, farmers were provided with adequate space to add more services.

\subsection{Method of Analysis and Model Specification}

Firstly, the institutional factors' dimension was reduced from an extensive dataset into a new set of a dataset using principal component analysis (PCA) [39]. PCA was counted among food security 
indicators like linear aggregation/geometric aggregation, z-score, global food index, and global hunger index [40]. PCA explains high variation in the data set using a small number of factors with similar weighting indicators that rely on data variability and variable correlation [40]. Subgroups with more variables have higher weight [40]. Relevant principal components (PCs) from the institutional factors were selected from a large group of institutional factors. An ordinary least square (OLS) regression was conducted from the projections of PCs and socio-economic factors to assess institutional factors' influence on scheme performance. Cronbach Alpha test was used to test the reliability of PCs. The PCA is easily understood among factor analyses (FA) as it reduces the dimension of datasets, increasing interpretability while minimizing information loss [41]. It is the most sought-after method for the analysis of nonlinear processes. PCA does not have redundancy of data, reduces complexity in image grouping, and reduces noise by choosing maximum variation [42]. The Breusch-Pagan/Cook-Weisberg test for heteroskedasticity was used to detect any linear form of heteroskedasticity of OLS. Robust standard errors were used to correct normality, heteroscedasticity, and some observations that exhibit large residuals. The OLS is a consistent method of regression that can be applied to single, multiple, or appropriately coded categorical explanatory variables; however, it mainly assumes linearity [43], which was satisfied by the data used for this study. To provide the best estimates from OLS, the following conditions were met:

- regression coefficients were linear,

- predictors uncorrelated with residuals,

- absence of serial correlation,

- absence of multicollinearity, and

- normality of residuals [43].

Model Description

Suppose a p-dimensional variable with mean $\mu$ is defined according to Equation (1):

$$
X^{T}=\left[X_{1}, \ldots, X_{P}\right]
$$

where $X=$ factors, $T=$ total, and $p=$ pth factor

To find a new set of variables $Y_{1}, Y_{2}, \ldots, Y_{p}$ (whose variance decrease from first to last), each $Y_{i}$ (principal component) is taken to be a linear combination of the $X_{j}$ (institutional factors) as shown in Equation (2):

$$
Y_{j}=a_{1 j} X_{1}+a_{2 j} X_{2}+\ldots+a_{p j} X_{p}
$$

where $a_{j}^{T}=\left[a_{1 j}, \ldots, a_{p j}\right]$.

OLS regression was performed with yield per hectare $(\mathrm{Y})$ as a dependent variable and socio-economic factors as independent variables. PCA reduced the number of variables and removed the multicollinearity of the independent variables [29]. A new set of factors, PCs, with same uncorrelated information as original, was produced (see Equation (3)):

$$
Y_{i}=a+b_{1} X_{1}+b_{2} X_{2}+\ldots+b_{m} X_{m}+C
$$

where $Y_{i}$-is the dependent variable; $X_{1}, X_{2}, \ldots, X_{m}$ are the independent variables; $a$-independent variables; $b_{1}, b_{2}, \ldots, b_{m}$ are the multiple regression coefficients.

\section{Results}

\subsection{Demographic Data and Socio-Economic Characteristics}

Basic household and socio-economic characteristics of respondents in the Tshiombo irrigation scheme are shown in Tables 1 and 2. The results show that three-quarters of the respondents were female. Among the respondents, almost half (46.9\%) of the female respondents were single. Ageing 
farmers constitute (average of 59 years) the majority of the respondents. Table 2 shows that there is a significant difference in the marital status of males $(91.4 \%)$ and female $(53.1 \%)$ respondents $(P<0.01)$. Each household had an average of 6 members. The majority of the respondents were literate (have attained formal education for an average of 8 years).

Table 1. Household characteristics.

\begin{tabular}{ccccc}
\hline Factor & Female & Male & Average & Standard Deviation \\
\hline Age of household head & 58.30 & 59.83 & 58.66 & 12.75 \\
Level of formal education & 7.38 & 9.03 & 8 & 4.29 \\
Number of household members & 6.34 & 6.49 & 6 & 2.74 \\
Household members work on plots & 1.64 & 1.51 & 2 & 1.09 \\
Years of household head in & 28.9 & 27.14 & 28.51 & 15.08 \\
irrigation & 1.30 & 1.26 & 1.27 & 1.27 \\
Plot size &
\end{tabular}

Source: Research survey, 2018.

Table 2. Socio-demographic factors.

\begin{tabular}{ccccc}
\hline Factor & Female (\%) & Male (\%) & Total (\%) & Significant Level \\
\hline Main occupation (irrigation farming) & 97.3 & 91.3 & 95.9 & $*$ \\
Marital status (Married & 53.1 & 91.4 & 92.2 & $*$ \\
Hire labor & 80.5 & 68.6 & 77.7 & \\
Formal training & 15 & 11.4 & 14.2 & \\
Livestock & 56.6 & 48.6 & 54.7 & \\
Plot ownership & 76.4 & 23.6 & 100 & \\
Subsidy & 66.4 & 62.9 & 65.5 & \\
Credit & 8 & 5.4 & 7.4 & \\
Farm cooperative & 50.4 & 62.9 & 53.4 & \\
Sweet potato & 87.6 & 94.3 & 89.2 & \\
Maize & 71.7 & 71.4 & 71.6 & \\
Groundnuts & 37.2 & 8.6 & 30.4 & \\
Bean & 25.7 & 28.6 & 26.4 & \\
Cabbage & 4.4 & 14.3 & 6.8 & \\
Spinach & 8.8 & 5.7 & 8.1 & \\
\hline
\end{tabular}

NB: ${ }^{* * *}, * *,{ }^{*}$ stands for significant at $1 \%, 5 \%$, and $10 \%$, respectively. Source: Research survey, 2018.

Sweet potato was the main crop grown by more than four-fifths of respondents (Table 2). The majority of the respondents grew sweet potato as they had easy access to seed and produce market. Sweet potato was likely to be rotated with maize. The latter was being produced by slightly less than three-quarters of the respondents. On the other hand, groundnuts, dry and green beans, cabbages, and spinach were produced by about a third, one quarter 6.8 , and 8.1 , respectively. Growing a wide range of crops contributes to crop diversification and the attainment of households and individuals' nutritional security. Cabbages and spinach were being grown by slightly less than $10 \%$ of the respondents.

There was a gender dimension on the growing of groundnuts and cabbages. More female respondents grew peanuts compared to male respondents $(P<0.01)$. On the other hand, the production of cabbage was dominated by male respondents $(P<0.05)$. The scientific literature on subsistence farming posits that subsistence crops are regarded as "female crops" and are grown by females at the household level. Cash crops and export crops are "male crops" that are produced by male farmers.

Table 3 shows that over $40 \%$ of farmers benefit from one or more LIAs. However, there is a gender dimension to the benefits as about four-fifth of the female farmers significantly benefit from the government compared to their male counterparts, who were only slightly more than half of the benefits $(p<0.01)$. 
Table 3. Percentage of scheme farmers who benefit from institutions.

\begin{tabular}{ccccc}
\hline \multirow{2}{*}{ Institutions } & \multicolumn{3}{c}{ Percentage } & \multirow{2}{*}{ Sig } \\
\cline { 2 - 4 } & Female & Male & Total & \\
\hline Government Agencies & 79.6 & 57.1 & 74.3 & $* * *$ \\
Traditional Leaders & 40.7 & 45.7 & 41.9 & \\
Cooperatives & 53.1 & 37.1 & 49.3 & $*$ \\
Private Organizations & 52.2 & 40.0 & 49.3 & \\
Academics Institutions & 52.2 & 40.0 & 49.3 & \\
Irrigation Committees & 72.6 & 71.4 & 72.3 & \\
Farming Community & 71.7 & 60.0 & 68.9 & \\
\hline
\end{tabular}

NB: ${ }^{* * *},{ }^{*}$ stands for significant at $1 \%$ and $10 \%$, respectively. Source: Research survey, 2018.

\subsection{Local Institutional Actors and Their Roles}

The results from Table 4 gives a summary of LIAs and their roles.

Table 4. Formal and informal local institutional actors and their roles.

\begin{tabular}{|c|c|c|}
\hline Type of Institutions & Local Institutional Actors & Roles \\
\hline \multirow{14}{*}{ Formal } & \multirow{3}{*}{ Government agencies } & Extension services \\
\hline & & Input subsidies \\
\hline & & Provide extension \\
\hline & \multirow[t]{2}{*}{ Academic institutions } & Provide market information \\
\hline & & Provide inputs information \\
\hline & \multirow{5}{*}{ Cooperatives } & Conflict management \\
\hline & & Provide loan/credit \\
\hline & & Easy access to market \\
\hline & & Scheme infrastructure maintenance \\
\hline & & Access to inputs markets \\
\hline & \multirow{3}{*}{ Private organizations } & Provide extension \\
\hline & & Provide inputs \\
\hline & & Provide market information for produce \\
\hline & Irrigation committee & Market information \\
\hline \multirow{6}{*}{ Informal } & \multirow{5}{*}{ Community } & Provide loan/credit \\
\hline & & Extension services \\
\hline & & Scheme infrastructure maintenance \\
\hline & & Provide inputs \\
\hline & & Provide market information for produce \\
\hline & Traditional leaders & Conflict management \\
\hline
\end{tabular}

Source: Research survey, 2018.

\subsection{Interpretation of Principal Components (PCs) Concerning Institutional Factors}

The results show the approximate of Chi-square value of 909.351 with 210 degrees of freedom, which is significant at the 0.01 level of significance. On the other hand, the Kaiser-Meyer-Olkin (KMO) statistic of 0.538 is greater than 0.50 ; hence, the data is appropriate for factor analysis.

\subsection{Reliability Test}

The Cronbach Alpha test below shows that the coefficients of variables are acceptable (Table 5). PCA leads to a satisfactory conclusion about LIAs. There is internal consistency among the set of factors. 
Table 5. Cronbach Alpha test for principal components.

\begin{tabular}{cc}
\hline Variables & Cronbach Alpha \\
\hline Overall Cronbach Alpha value & 0.78 \\
Community cooperative support & 0.94 \\
Extension and conflict management support & 0.81 \\
Input, conflict management, and market support & 0.79 \\
Inputs and market support & 0.61 \\
Extension and input support & 0.71 \\
Academic institutions input support & 0.86 \\
Community maintenance support & 0.69 \\
Community input support & 0.83 \\
\hline
\end{tabular}

Source: estimated from research survey, 2018.

\subsection{Institutional Dimension}

PCA shows the relatedness of institutional factors within each rotated component and could be highly associated with a group of farmers' physical location. Factor COM_CRDT consists of farmers who were accessing "soft" loans from the community (0.761) (Table 6). In the Tshiombo irrigation scheme, some farmers access loans from cooperative loan schemes (0.554). Among farmers that are characterized by the COOP_EXT factor, traditional leaders (0.518) manage conflicts emerging from access to inputs from private organizations (0.807) and access to market (0.560) (Table 6). Besides, farmers access extension services from academic institutions (0.839), private organizations (0.628), and extension workers (0.527), which impart them with marketing skills, which enable them to sell their products at competitive prices. In factor ACA_INST, academic institutions play a pivotal role by contacting farmer-based research and giving feedback, though they do not provide market information. Factor COM_MANT consists of farmers who took part in scheme maintenance.

Table 7 below gives a summary of principal components in Table 6 above.

\subsection{Regression Model Diagnostic}

The yield of sweet potato was a dependent variable since it was the main crop produced by more than four-fifths of the respondents. The return of sweet potato was standardized by log-normalizing to take care of outliers [44]. The Breusch-Pagan/Cook-Weisberg test shows that heteroscedasticity was significant $(P<0.01)$. Furthermore, $59.39 \%$ of the variance is explained by this model. Therefore, in relation to the F-test, the model is statistically significant to the analysis.

\subsection{Factors Affecting Crop Yield}

The yield of sweet potato was significantly impacted by COM_CRDT $(P<0.01)$, COM_MANT $(P<0.01)$, COOP_EXT $(P<0.05)$, ACA_INST $(P<0.05)$, and COM_INPT $(P<0.1)$ (Table 8$)$. The yield of sweet potato was positively impacted by the factor COM_CRDT. A unit increase in COM_CRDT, COM_MANT, and ACA_INST significantly increases the sweet potato yield by a margin of $0.49,0.362$, and 0.116 , respectively. 
Table 6. Principal component analysis (PCA) results on the proportion of institutional factors on principal components.

\begin{tabular}{|c|c|c|c|c|c|c|c|c|}
\hline \multicolumn{9}{|c|}{ Rotated Component Matrix } \\
\hline \multirow{2}{*}{ Institutional Factor } & \multicolumn{8}{|c|}{ Component } \\
\hline & 1 & 2 & 3 & 4 & 5 & 6 & 7 & 8 \\
\hline Cooperatives provide maintenance & 0.671 & -0.037 & 0.038 & 0.056 & 0.033 & -0.155 & -0.225 & 0.027 \\
\hline Cooperatives provide loan & 0.554 & -0.031 & 0.221 & 0.115 & 0.097 & 0.114 & 0.378 & 0.209 \\
\hline Cooperatives provide market & 0.529 & 0.078 & -0.051 & 0.032 & 0.326 & 0.357 & 0.119 & 0.240 \\
\hline Private organizations provide extension & 0.115 & 0.628 & -0.228 & 0.105 & -0.179 & -0.037 & 0.347 & 0.102 \\
\hline Extension officers provide extension & 0.320 & 0.527 & 0.469 & 0.254 & 0.023 & 0.156 & -0.083 & 0.048 \\
\hline Private organizations provide inputs & 0.188 & 0.024 & 0.807 & -0.286 & 0.135 & 0.069 & -0.040 & 0.096 \\
\hline Irrigation committees provide market & 0.204 & -0.014 & 0.560 & 0.179 & -0.212 & -0.149 & 0.221 & 0.003 \\
\hline Tradition leaders conflict management & -0.170 & 0.458 & 0.518 & 0.295 & 0.329 & -0.205 & -0.032 & 0.002 \\
\hline Cooperatives provide inputs & 0.077 & -0.003 & 0.143 & 0.834 & -0.125 & 0.144 & 0.015 & 0.167 \\
\hline Academic institutions provide market & 0.081 & -0.268 & 0.189 & 0.141 & 0.251 & -0.740 & 0.061 & -0.147 \\
\hline Academic institutions provide inputs & 0.087 & -0.244 & 0.119 & 0.310 & 0.078 & 0.733 & 0.235 & -0.119 \\
\hline Community provide maintenance & -0.039 & -0.006 & 0.063 & -0.009 & -0.005 & 0.092 & 0.730 & 0.061 \\
\hline Community provide inputs & 0.207 & 0.191 & 0.179 & 0.034 & 0.114 & 0.106 & 0.022 & 0.778 \\
\hline Community provide market & 0.520 & 0.283 & 0.204 & 0.080 & -0.082 & 0.132 & -0.208 & -0.525 \\
\hline Eigenvalue & 2.34 & 2.28 & 1.87 & 1.81 & 1.74 & 1.54 & 1.45 & 1.34 \\
\hline Percentage of Variance & 11.15 & 10.86 & 8.92 & 8.61 & 8.29 & 7.33 & 6.89 & 6.39 \\
\hline Cumulative percent & 11.15 & 22.01 & 30.93 & 39.54 & 47.83 & 55.17 & 62.06 & 68.45 \\
\hline
\end{tabular}

Source: estimated from research survey, 2018. 
Table 7. Variable definition of institutional factors.

\begin{tabular}{|c|c|c|}
\hline Variable & Code & Description \\
\hline 1 Community cooperative support & COM_CRDT & $\begin{array}{l}\text { Farmers access loan from community and cooperatives, } \\
\text { participate in cooperative scheme maintenance, access to the } \\
\text { market for their products through cooperatives, and sell their } \\
\text { produce to the local community. }\end{array}$ \\
\hline $\begin{array}{l}2 \text { Extension and conflict } \\
\text { management support }\end{array}$ & ACA_EXT & $\begin{array}{l}\text { Farmers dominantly access extension services from academic } \\
\text { institutions, extension officers, and private organizations. They } \\
\text { are also privileged to access traditional leaders and cooperatives } \\
\text { for conflict management. }\end{array}$ \\
\hline $\begin{array}{l}3 \text { input, conflict management, and } \\
\text { market support }\end{array}$ & PVT_ORG_INPT & $\begin{array}{l}\text { Farmers mainly access inputs from private organizations and } \\
\text { rely on traditional leaders for conflict management. They as well } \\
\text { rely on the irrigation committee to access the market. }\end{array}$ \\
\hline 4 Inputs and market support & COOP_INPT & $\begin{array}{l}\text { Farmers access input subsidy from cooperatives and markets } \\
\text { from private institutions. }\end{array}$ \\
\hline 5 Extension and input support & COOP_EXT & $\begin{array}{c}\text { Farmers access extension services from cooperatives and } \\
\text { subsidized inputs by the government. }\end{array}$ \\
\hline $\begin{array}{l}6 \text { Academic institutions input } \\
\text { support }\end{array}$ & ACA_INST & $\begin{array}{l}\text { Farmers access input subsidies from academic institutions, but } \\
\text { they do not access the market from them. }\end{array}$ \\
\hline $\begin{array}{c}7 \text { Community maintenance } \\
\text { support }\end{array}$ & COM_MANT & Farmers participate in community scheme maintenance. \\
\hline 8 Community input support & COM_INPT & $\begin{array}{l}\text { Farmers access inputs from the community but are less likely to } \\
\text { rely on the local community for the market of their produce. }\end{array}$ \\
\hline
\end{tabular}

Source: estimated from research survey, 2018.

Table 8. Ordinary least square (OLS)results on the relationship between the yield of sweet potato and institutional factors, social factors, and managerial factors.

\begin{tabular}{ccc}
\hline Factor & Coef. & Robust Std. Err. \\
\hline Age & -0.01 & 0.01 \\
Gender & -0.06 & 0.13 \\
Marital Status & 0.10 & 0.13 \\
Formal Education & -0.01 & 0.01 \\
Number of household members & -0.00 & 0.02 \\
Years farming in irrigation & 0.00 & 0.00 \\
Formal Agricultural Training & -0.12 & 0.14 \\
Distance to the Markets & -0.12 & 0.07 \\
Fertilizer Subsidies & -0.00 & 0.00 \\
Pesticide subsidies & 0.04 & 0.04 \\
Hawking & -0.00 & 0.00 \\
COM_CRDT & $0.49^{* * *}$ & 0.06 \\
ACA_EXT & 0.08 & 0.05 \\
PVT_ORG_INPT & 0.03 & 0.05 \\
COOP_INPT & 0.08 & 0.06 \\
COOP_EXT & $0.12^{* *}$ & 0.06 \\
ACA_INST & $0.1 * *$ & 0.05 \\
COM_MANT & $0.36^{* * *}$ & 0.06 \\
COM_INPT & $0.10^{*}$ & 0.06 \\
Livestock Unit & -0.01 & 0.01 \\
Asset indices & -0.08 & 0.22 \\
\hline
\end{tabular}

NB: ***,**,* stands for significant at 1\%,5\%, and 10\%, respectively. Source: estimated from research survey, 2018.

\section{Discussion}

There is limited access to loans from formal financial institutions due to lack of collateral security; therefore, cooperatives and local communities act as a buffer through access to soft loans. Loans improve access to markets, allowing farmers to bargain for more competitive market prices, enabling the farmers in cooperatives to easily and timely market their products. However, it is not easy to substantially improve food and nutritional security without access to financial services and being commercially oriented [43]. Knowledge obtained through participating in cooperatives prompted 
farmers to alternatively rely on each other for soft loans [45]. Marketing skills acquired through participating in cooperatives (0.529) enable farmers in COM_CRDT to access market information from the community easily. According to Perret et al. [32], farmers fail to acquire economic, financial, and managerial skills from extension officers; this inherent problem among schemes in Limpopo province might have prompted to acquire some through cooperatives. The acquisition of knowledge and skills by the farmers is vital for the economic viability of smallholder farming. These findings acknowledge the literature by Miller [24]. They recognize the collaboration of various institutional actors in bringing together fragments of knowledge and contributions to achieve a common food and nutritional security goal.

Among farmers that are characterized by the COOP_EXT factor, traditional leaders (0.518) manage conflicts emerging from access to inputs from private organizations (0.807) and access to market $(0.560)$ (Table 6). Traditional leaders are hierarchical institutions in authority to assure adherence to social norms, regulations, and law by all members [24]. Besides, farmers access extension services from academic institutions (0.839), private organizations (0.628), and extension workers (0.527), which impart them with marketing skills, which enable them to sell their products at competitive prices. The challenge of the technical functions of extension workers noted by Perret et al. [32] could have prompted farmers and scheme management to diversify sources for their required skills. That is, extension services are among the technical assistance provided to SISs in South Africa $[10,33]$. Evidence from this study shows that the source of extension services varies with individual farmers' choices. Extension workers are responsible, jointly with academic institutions, to provide extension services to the farmers [24]. Challenges of extension officers delivering services at the individual level and not at the scheme level as observed in the Thabina scheme [32] were not observed. Access to extension services enables farmers to diversify, adopt water-saving technologies and management, introduce new crops, and strategies to spread risks across space or time [34].

In factor ACA_INST, academic institutions play a pivotal role by contacting farmer-based research and giving feedback, though they do not provide market information. Factor COM_MANT consists of farmers who took part in scheme maintenance. Therefore, farmers near the tail end did not participate in scheme maintenance, taking into account abysmal access to irrigation water. Wide variation in water access and its impact on irrigation performance in SISs associated with the location was noted to disadvantage tail-end farmers in South Africa severely [30,36]. Farmers who constitute COM_INPT have poor access to markets due to uncompetitive conflict management; this contributes to poor performance despite adequate access to inputs from fellow scheme farmers. The majority of smallholder farmers in SSA select healthy sweet potato vines from previous year plots or obtain them from their neighbors [46].

The participation of LIAs contributes to the performance of the Tshiombo irrigation scheme. The LIAs that include the government, cooperatives, private organizations, academic institutions, traditional leaders, and the general community were recognized for their supportive role in the scheme. Table 3 shows that the government positively addresses gender imbalances by supporting women who are both socially and economically disadvantaged compared to their male counterparts [47]. Offering support to female farmers who dominantly participate in the scheme is key to improving performance, household food security, and ensuring the sustainability of the schemes [48]. Female farmers significantly benefit from cooperatives compared to male farmers $(p<0.01)$. The support which female farmers receive from LIAs contributes towards ensuring nutritional adequacy, increasing productivity, raising rural income, improving environmental management, poverty eradication, and improving livelihoods among the rural poor [5,49].

The roles of institutions relate to the performance of smallholder irrigation. Addressing irrigation schemes' performance challenges is important for improved water productivity, food security, and improved climate change resilience. [31,39]. Table 8 shows that institutional factors positively affect scheme performance at a statistically significant level. Institutional factors were used as the independent variable to yield of sweet potato. 
COM_CRDT and yield of sweet potato are positively correlated, given that access to services that make up this factor result in an increase of yield of sweet potato with a margin of 0.49 . At the same time, there is developing evidence that accessing credit from community members was an alternative solution to financial challenges in the scheme. The literature states that smallholder communal farmers face challenges in accessing credit from formal financial institutions like banks [50]. These challenges are due to institutional actors' failure to focus on improving food security by boosting income and reducing poverty among rural communities [5,49]. Based on such results, the study backed the findings, which alluded that traditional savings in the form of credit cooperatives are adequate access to credit in irrigation schemes [51,52]. The major challenge with traditional savings (saving under the pillow) is that they are not sufficient to support the scheme's development needs. In addition, they are not secure as a lot of uncertainties shrouds their availability. Thus, it brings more attention to the lack of collateral, lack of credit information, fear of the penalty defaulting payment, high interest and distance of financial institutions from the scheme, and other factors suggested by scheme farmers that impact loan access from credit facilities [12]. Moreover, land use and occupation are through permission to occupy, which cannot be used as collateral to access banks' money.

Empirical findings show that $53.4 \%$ of scheme farmers are members of cooperatives. Therefore, we see that farmers in the same village or irrigation block who share similar challenges were most likely to collectively meet and negotiate based on the nature of the relationship between them. For numerous reasons, LIAs are needed to strengthen cooperatives to implement agricultural innovation [5]. Farmers in the same neighborhood have standard practices and challenges; hence, a common and collective approach may be required to address the challenges. That is, SIS's poor performance can be pointed at a lack of collective action of LIAs to support others like cooperatives [24].

Factor COM_MANT significantly improves the performance of the scheme. The performance of irrigation schemes is mainly anchored on reliable access to irrigation water; therefore, maintenance of irrigation canal infrastructure may ensure a constant flow of water and reduce water losses through leakages [11]. Interviews with KIIs and FGDs show that the community regularly engages in contributing money for scheme maintenance and participating in canal maintenance [11]. Given that there is a limited engagement of LIAs in scheme maintenance, there is insufficient investment in advanced technology, making scheme farming more attractive to young farmers. Including agricultural research and investment reforms in the maintenance of rural infrastructure will aid the achievement of food security, boosting income, and poverty reduction [5]. Furthermore, farmers modify and formulate collective rules that emphasize all scheme members to participate in scheme maintenance. The participation of farmers in meetings does not guarantee their involvement in scheme maintenance due to the lack of written rules and formal laws binding their involvement in the maintenance of irrigation infrastructure [11,30]. This consequently results in the problem of defaulting of payment and subsequently in non-participation by some scheme farmers. Findings from the study resonate with what Mdimu et al. [51] have accentuated that farmers' participation in scheme maintenance is challenged by insufficient payment of maintenance fee and low participation in infrastructure maintenance, deteriorating reliability and timely water access by farmers at the tail-end. In this regard, traditional chiefs have been proven to be the best alternative solution to resolve related conflicts in the Tshiombo irrigation scheme.

Simultaneously, getting recommendations on inputs from academic institutions may facilitate farmers to access improved seed varieties, which meet the local and international markets' demand as they might have gone through market-led research. Accordingly, LIAs can help to create more effective and efficient safety nets [49]. Nevertheless, access to the market from institutions have minimum impact on scheme performance. On the other hand, although academic institutions do not provide product market, KIIs and FGDs meetings factor out that they play a pivotal role in providing market information, enabling farmers to make informed decisions on accessing the market.

Factor COOP_EXT has resulted in an increase in the yield of sweet potato by 0.12 . Despite this, cooperatives in the scheme were not established with a mandate to offer extension services, but it is 
accessed through platforms and networking with organizations that support them. These findings relate to the study by Mapeza et al. [9], which identifies cooperatives' role in the provision of extension support. In addition, KIIs interviews show that farmers in cooperatives are loyal to the rules of the unions; therefore, in this regard, they can easily acquire extension services through them. Given that female farmers significantly dominate cooperatives; they are benefiting from extension through cooperatives than male farmers.

Access to extension services from the community and access to subsidies from the government has a higher loading greater than 0.3 in COM_MANT and COOP_EXT, impacting the yield of sweet potato positively at statistically significant levels. These findings highlight the importance of these roles to scheme performance since they have contributed notably to sweet potato return. A review by Sharaunga and Mudhara [11] state that community institution determines the success of outcomes. Indeed, access to extension services from the community proves that indigenous knowledge is essential to improve scheme performance. Among these, agricultural input subsidies are targeted to smallholder resource-poor farmers in conjunction with extension services in South Africa [53]. On the same note, although subsidies were acquired in the scheme, most grants target crops of economic value to the government in contrast to farmers' choice, resulting in most grants being underutilized.

The SIS institutional actors' significance is reflected by their role in improving yield, ensuring food and nutritional security, reducing poverty, transforming livelihoods of the rural economies and effectively reducing inequality and hunger [3]. It works when institutions' intellectual cooperation is reached to achieve a common goal in an institutional context [24]. The LIAs in SIS should have a collective moral responsibility for joint action to avoid future hunger. The LIAs can transform rural communities into economic hubs by supporting SIS through imparting skills, access to credit, and technological advancement.

Findings from the study show that each LIAs has numerous roles. However, the absence of clear inter-institutional coordination among the LIAs in the scheme results in some positive and negative outcomes in the scheme. This scenario helps farmers to access some services from diverse LIAs. On the other hand, it results in lack of accountability of LIAs, thereby affecting farmers' access to essential services, resulting in the decrease in the scheme's performance. In addition, the existence of poor inter-institutional coordination among LIAs complicates access to critical services by farmers due to uncompleted tasks by some LIAs. On the other note, farmers' access to critical services from a LIA is overshadowed by access to multiple services from the same actor. In the case of extension officers, their role in distributing inputs subsidies weakens their relationship with farmers who assume unfair distribution of subsidies, but this may deprive farmers' access to extension services. In addition, some farmers view extension workers as distributors of subsidies compared to offering extension services.

Given that there were various LIAs offering a single service, poor engagement and competition between these actors widen the conflicts between the actors, hence compromising access to key services by scheme farmers. It was also noted that some institutions advance their commercial interest at the expense of offering the necessary services to the farmers. However, the existence of various institutions working with farmers implies that the "Market for lemons" scenario does not exist, where scheme farmers have asymmetric information on certain services, for example, price of commodities.

\section{Conclusions}

This study was conducted to identify institutional services that impact the performance of Tshiombo irrigation schemes. Results have highlighted that institutional factors significantly influenced the performance of SISs. Combined institutional factors determine the yield of sweet potato, and hence, performance in the system. However, farmers access numerous services from diverse LIAs. Therefore, LIAs play a decisive role in the management and support of SISs.

Yet, services from various LIAs accessed by farmers may be used to determine services needed by farmers and preferred service providers to improve scheme performance. The use of PCA revealed that challenges faced by some LIAs are corrected by services offered by the other. However, the inability 
to properly incorporate LIAs in small-scale irrigation schemes will scale up irrigation management challenges among numerous farmer-managed irrigation schemes, reducing scheme performance. This has been worsened by a lack of systematic impact assessment and evaluation of irrigation management policies implemented by governments and international funding institutions for SIS in developing countries. This is an addition to the dearth of literature on management strategies that improve the scheme's ability to improve productivity, maximize profitability, and ensure effective operation and maintenance.

Thus, SIS farmers are made up of heterogeneous groups that differ in their features, have diverse responses to incentives, unequal opportunities, and vary in constraints they face, which affect their decision on the choice of services they acquire from each LIA. Therefore, understanding SISs' complex nature will help provide a combination of institutional services that will address each farmer typology's needs and improve scheme performance and sustainability. Concurrently, organizing and grouping of farmers with similar circumstances is needed to enable them to benefit from interaction and easy training and sharing of services. Thus, scheme institutional actors must consider the diversity of scheme farmer typology when offering their services to achieve a common goal. The LIAs' services to scheme farmers should address the heterogeneity of smallholder farmers since they have different institutional services choices in relation to the heterogeneous nature of farming groups. However, the impact of LIAs on scheme performance is determined by the quality of services and the nature of relation building between them and scheme farmers. Based on this study's results, there is a need to pull diverse ideas and solutions for SIS by setting up innovation platforms at the local, intermediary, and national levels. Future study needs to focus on the imbalance of power caused by imperfect information that deters sound decision-making, negatively impacting LIAs and farmers' relations and reducing the scheme performance. Finally, the study suggests that LIAs in irrigation schemes play multiple roles; however, their interaction needs further study to reduce conflicts and duplication and better understand how they can benefit the local communities and improve scheme performance.

Author Contributions: Conceptualization, All; methodology, L.M. and R.M.; software, L.M.; validation, R.M. and P.M.; formal analysis, L.M.; investigation, L.M.; resources, P.M.; data curation, L.M.; writing-Original draft preparation, L.M.; writing-Review and editing, L.M. and R.M.; visualization, L.M.; supervision, R.M. and P.M.; project administration, P.M.; funding acquisition, P.M. All authors have read and agreed to the published version of the manuscript

Funding: This research was funded by South Africa's National Research Foundation (NRF) grant number (86893) for study and collection.

Acknowledgments: The authors acknowledge NRF for funding this study. DAFF in Thulamela municipality, extension workers and farmers in Tshiombo Irrigation Scheme are honored for their contributions for the success of this study.

Conflicts of Interest: The authors declare no conflict of interest. The funders had no role in the design of the study; in the collection, analyses, or interpretation of data; in the writing of the manuscript, or in the decision to publish the results.

\section{References}

1. Wegenast, T.; Beck, J. Mining, rural livelihoods and food security: A disaggregated analysis of sub-Saharan Africa. World Dev. 2020, 130, 104921. [CrossRef]

2. Swidiq, M. The Potential of Well Designed Early Warning Systems and Disaster Insurance Schemes in Cushioning Farmers Against Drought-induced Agricultural Losses in the Karamoja Sub-region of Uganda. Sci. Agric. 2013, 3, 19-25.

3. Lowder, S.K.; Skoet, J.; Raney, T. The number, size, and distribution of farms, smallholder farms, and family farms worldwide. World Dev. 2016, 87, 16-29. [CrossRef]

4. Zingore, S.; Mutegi, J.; Agesa, B.; Tamene, L.; Kihara, J. Soil degradation in sub-Saharan Africa and crop production options for soil rehabilitation. Better Crops 2015, 99, 24-26.

5. Rosegrant, M.W.; Cline, S.A. Global food security: Challenges and policies. Science 2003, 302, $1917-1919$. [CrossRef] 
6. Molobela, I.P.; Sinha, P. Management of water resources in South Africa: A review. Afr. J. Environ. Sci. Technol. 2011, 5, 993-1002.

7. Booysen, M.; Wijesiri, B.; Ripunda, C.; Goonetilleke, A. Fees and governance: Towards sustainability in water resources management at schools in post-apartheid South Africa. Sustain. Cities Soc. 2019, 51, 101694. [CrossRef]

8. Denby, K.; Movik, S.; Mehta, L.; van Koppen, B. The 'trickle down' of IWRM: A case study of local-level realities in the Inkomati Water Management Area, South Africa. Water Altern. 2016, 9, 473-492.

9. Mapedza, E.; Van Koppen, B.; Sithole, P.; Bourblanc, M. Chemistry of the Earth, P.A.B.C. Joint venture schemes in Limpopo Province and their outcomes on smallholder farmers livelihoods. Phys. Chem. Earth Parts A/B/C 2016, 92, 92-98. [CrossRef]

10. Ncube, B. Institutional support systems for small-scale farmers at new forest Irrigation Scheme in Mpumalanga, South Africa: Constraints and opportunities. S. Afr. J. Agric. Ext. 2017, 45, 1-13.

11. Sharaunga, S.; Mudhara, M. Chemistry of the Earth, P.A.B.C. Determinants of farmers' participation in collective maintenance of irrigation infrastructure in KwaZulu-Natal. Phys. Chem. Earth Parts A/B/C 2018, 105, 265-273. [CrossRef]

12. Sinyolo, S.; Mudhara, M.; Wale, E. The impact of smallholder irrigation on household welfare: The case of Tugela Ferry irrigation scheme in KwaZulu-Natal, South Africa. Water SA 2014, 40, 145-156. [CrossRef]

13. Muchara, B.; Ortmann, G.; Mudhara, M.; Wale, E. Irrigation water value for potato farmers in the Mooi River Irrigation Scheme of KwaZulu-Natal, South Africa: A residual value approach. Agric. Water Manag. 2016, 164, 243-252. [CrossRef]

14. van Rooyen, A.F.; Ramshaw, P.; Moyo, M.; Stirzaker, R.; Bjornlund, H. Theory and application of agricultural innovation platforms for improved irrigation scheme management in Southern Africa. Int. J. Water Res. Dev. 2017, 33, 804-823. [CrossRef]

15. Musvoto, C.; Nahman, A.; Nortje, K.; de Wet, B.; Mahumani, B.J.C.f.S.; Industrial Research, S.A. Agriculture and the Green Economy in South Africa; A CSIR Analysis: Pretoria, South Africa, 2014.

16. Department of Agriculture; Processed Food \& Bev. Trade SA. Forestry and Fisheries; Malachite Publishing: Pretoria, South Africa, 2018.

17. Van Averbeke, W.; Denison, J.; Mnkeni, P. Smallholder irrigation schemes in South Africa: A review of knowledge generated by the Water Research Commission. Water SA 2011, 37, 797-808. [CrossRef]

18. Denison, J.; Dube, S.; Masiya, T.; Moyo, T.; Murata, C.; Mpyana, J.; van Averbeke, L.; Van Averbeke, W. Smallholder Irrigation Entrepreneurial Development Pathways and Livelihoods in Two Districts in Limpopo Province. Water Res. 2016, 16, 1-9.

19. Fanadzo, M.; Chiduza, C.; Mnkeni, P. Overview of smallholder irrigation schemes in South Africa: Relationship between farmer crop management practices and performance. Afric. J. Agric. Res. 2010, 5, 3514-3523.

20. van Koppen, B.; Nhamo, L.; Cai, X.; Gabriel, M.J.; Sekgala, M.; Shikwambana, S.; Tshikolomo, K.; Nevhutanda, S.; Matlala, B.; Manyama, D. Smallholder Irrigation Schemes in the Limpopo Province, South Africa; International Water Management Institute: Pretoria, South Africa, 2017; Volume 174.

21. Ostrom, E. Governing the Commons: The Evolution of Institutions for Collective Action; Cambridge University Press: London, UK, 1990.

22. North, D.C. Institutions. J. Econ. Perspect. 1991, 5, 97-112. [CrossRef]

23. Agrawal, A. The Role of Local Institutions in Adaptation to Climate Change; World Bank Group: Washington, DC, USA, 2008.

24. Miller, S. Dual Use Science and Technology, Ethics and Weapons of Mass Destruction; Springer: Canberra, Australia, 2018; pp. 39-54.

25. Spangenberg, J.H.; Pfahl, S.; Deller, K. Towards indicators for institutional sustainability: Lessons from an analysis of Agenda 21. Ecol. Indic. 2002, 2, 61-77. [CrossRef]

26. Asif, M.; Majid, A. The Role of Institutions in Energy Policy and Environmental Protection. In Dynamics of Energy, Environment and Economy; Springer: Berlin, Germany, 2020; pp. 225-239.

27. Ostrom, E. Beyond markets and states: Polycentric governance of complex economic systems. Am. Econ. Rev. 2010, 100, 641-672. [CrossRef] 
28. Rahman, H.; Saint Ville, A.; Song, A.; Po, J.; Berthet, E.; Brammer, J.; Brunet, N.; Jayaprakash, L.; Lowitt, K.; Rastogi, A. A framework for analyzing institutional gaps in natural resource governance. Int. J. Commons 2017, 11, 823-853. [CrossRef]

29. Indraprahasta, G.S.; Derudder, B.; Hudalah, D. Local institutional actors and globally linked territorial development in Bekasi District: A strategic coupling? Singap. J. Trop. Geogr. 2019, 40, 219-238. [CrossRef]

30. Sharaunga, S.; Mudhara, M. Factors influencing water-use security among smallholder irrigating farmers in Msinga, KwaZulu-Natal Province. Water Policy 2016, 18, 1209-1228. [CrossRef]

31. Mapani, B.; Makurira, H.; Magole, L.; Meck, M.; Mkandawire, T.; Mul, M.; Ngongondo, C. Innovative solutions for intractable water problems in the face of climate change in southern and East African sub regions. Phys. Chem. Earth 2018, 105, 1-2. [CrossRef]

32. Perret, S.; Lavigne, M.; Stirer, N.; Yokwe, S.; Dikgale, K. The Thabina Irrigation Scheme in a Context of Rehabilitation and Management Transfer. Prospective Analysis and Local Empowerment: Assessing the Economic Viability of Smallholder Irrigation Schemes in South Africa; Final Report, Project number, 2003-068, CIRAD; Food and Agriculture Organization of the United Nations: Rome, Italy, 2003; pp. 15-31.

33. Partelow, S. A review of the social-ecological systems framework: Applications, methods, modifications, and challenges. Ecol. Soc. 2018, 23, 36. [CrossRef]

34. Ostrom, E. Background on the institutional analysis and development framework. Policy Stud. J. 2011, 39, 7-27. [CrossRef]

35. Fanadzo, M.; Ncube, B. Challenges and opportunities for revitalising smallholder irrigation schemes in South Africa. Afr. J. Online 2018, 44, 436-447.

36. Keetelaar, E.G. Combining Approaches to Assess Economic Viability and Institutional Arrangements in Smallholder Irrigation Schemes: A Case Study in the Mauluma Irrigation Scheme Limpopo Province-South Africa; ENGREF: Pretoria, South Africa, 2004.

37. Mpandeli, S.; Nesamvuni, E.; Maponya, P. Adapting to the impacts of drought by smallholder farmers in Sekhukhune District in Limpopo Province, South Africa. J. Agric. Sci. 2015, 7, 115. [CrossRef]

38. Cai, X.; Magidi, J.; Nhamo, L.; van Koppen, B. Mapping Irrigated Areas in the Limpopo Province, South Africa; International Water Management Institute (IWMI): Colombo, Sri Lanka, 2017; Volume 172.

39. Chatfield, C.; Collins, A. Introduction to Multivariate Analysis; CRC Press: Boca Raton, FL, USA, 1981; Volume 1.

40. Santeramo, F.G.J.F.R.I. On the composite indicators for food security: Decisions matter! Food Rev. Int. 2015, 31, 63-73. [CrossRef]

41. Jolliffe, I.T.; Cadima, J. Principal component analysis: A review and recent developments. Math. Phys. Eng. Sci. 2016, 374, 20150202. [CrossRef]

42. Karamizadeh, S.; Abdullah, S.M.; Manaf, A.A.; Zamani, M.; Hooman, A.; Processing, I. An overview of principal component analysis. J. Signal Inf. Process. 2013, 4, 173. [CrossRef]

43. Hutcheson, G.D.; Moutinho, L. Ordinary Least-Squares Regression. In The SAGE Dictionary of Quantitative Management Research; SAGE Publications Ltd.: Thousand Oaks, CA, USA, 2011; pp. 224-228.

44. Marino, M.; Li, Y.J.S.T.; Fields, R. Factor analysis of correlation matrices when the number of random variables exceeds the sample size. Stat. Theory Related Fields 2017, 1, 246-256. [CrossRef]

45. Sinyolo, S.; Mudhara, M. The impact of entrepreneurial competencies on household food security among smallholder farmers in KwaZulu Natal, South Africa. Ecol. Food Nutr. 2018, 57, 71-93. [CrossRef] [PubMed]

46. McEwan, M.; Almekinders, C.; Abidin, P.; Andrade, M.; Carey, E.; Gibson, R.; Naico, A.; Namanda, S.; Schulz, S. Can small still be beautiful? Moving local sweetpotato seed systems to scale in sub-Saharan Africa. In Potato Sweetpotato in Africa: Transforming the Value Chains for Food Nutrition Security; CIP: Addis Ababa, Ethiopia, 2015; pp. 289-310.

47. Flatø, M.; Muttarak, R.; Pelser, A. Women, weather, and woes: The triangular dynamics of female-headed households, economic vulnerability, and climate variability in South Africa. World Dev. 2017, 90, 41-62. [CrossRef]

48. Mudhara, M.; Senzanje, A. Assessment of policies and strategies for the governance of smallholder irrigation farming in Kwazulu-Natal province, South Africa. Water Res. Commons 2020. [CrossRef]

49. Maxwell, S. Food security: A post-modern perspective. Food Policy 1996, 21, 155-170. [CrossRef]

50. Senyolo, M.P.; Long, T.B.; Blok, V.; Omta, O. How the characteristics of innovations impact their adoption: An exploration of climate-smart agricultural innovations in South Africa. J. Clean. Prod. 2018, 172, 3825-3840. [CrossRef] 
51. Mdemu, M.V.; Mziray, N.; Bjornlund, H.; Kashaigili, J.J. Barriers to and opportunities for improving productivity and profitability of the Kiwere and Magozi irrigation schemes in Tanzania. Int. J. Water Res. Dev. 2017, 33, 725-739. [CrossRef]

52. Kwai, M.D.; Urassa, J.K. The contribution of savings and credit cooperative societies to income poverty reduction: A case study of Mbozi District, Tanzania. J. Afr. Stud. Dev. 2015, 7, 99-111.

53. Kassie, M.; Teklewold, H.; Jaleta, M.; Marenya, P.; Erenstein, O. Understanding the adoption of a portfolio of sustainable intensification practices in eastern and southern Africa. Land Use Policy 2015, 42, 400-411. [CrossRef]

(C) 2020 by the authors. Licensee MDPI, Basel, Switzerland. This article is an open access article distributed under the terms and conditions of the Creative Commons Attribution (CC BY) license (http://creativecommons.org/licenses/by/4.0/). 